\title{
A learner perspective on the implementation of Geographic Information Systems in selected schools in KwaZulu-Natal province
}

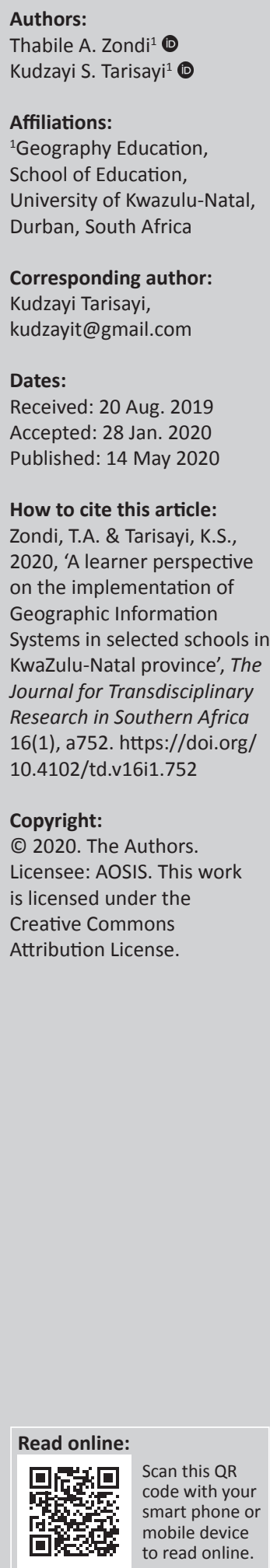

Contemporary literature reveals a plethora of studies on the implementation of Geographic Information System (GIS) in South Africa. However, these studies provide an educator's perspective while neglecting the learner's perspective, which is provided in this study. The researchers used a qualitative collective case study in the interpretivist paradigm. A purposive sample of five schools and 50 grade 12 learners was used in this study. The data were generated using observations, five focus group discussions and 10 interviews. This study established that the learners lacked fundamental knowledge of GIS and that GIS was not being properly taught.

Keywords: Geographic Information Systems; learners' perspective; KwaZulu-Natal; educators' perspectives.

\section{Introduction}

In contemporary years, there has been widespread and renewed attention by academics in general and geographers in particular in enhancing Geographic Information System (GIS) implementation in schools (Breetzke, Elsteen \& Pretorious 2011; Kerski 2003; Tarisayi 2018). An academic focus on GIS in schools stems from the recognition that the Information Communications Technology (ICT) integration is at the very core of educational innovation. In addition, GIS in schools is informed by the broad field of Geographic Information Science (GIScience). Wilson and Fotheringham (2007) state that GIScience is theoretically interrelated to geography, information science, computer science, geomatics and geoinformatics. It is against this background of ICT integration and GIScience that GIS is being implemented in schools in South Africa. This article begins by providing a background to this study which defines GIS and reviews literature on GIS implementation. The authors present a conceptual framework justifying an understanding of the learner's perspective of doing GIS in geography. The next section chronicles the research methodology used in this study. Findings of this study are presented before the concluding remarks.

\section{Conceptualisation of Geographic Information System}

A number of studies have explored the concept of GIS in recent years. The origin of GIS is traced to the Canadian Land Inventory system developed in the 1960s (Kerski, Demirci \& Milson 2013). Innes (2012:92) reveals that 'we are in the early phase of Geographic Information System (GIS) development in South Africa, where the majority of users are utilities such as municipalities and water and electricity suppliers'. Geographic Information System has been viewed by many geographers as an outcome of computerisation (Ozgen 2009; Palladino 1994; Tarisayi 2018). Thus, GIS stems from endeavours to computerise the manipulation of geographical data. Generally, 'GIS is a computerbased platform that integrates a multiplicity of data sets to digitally represent and analyse the geographic features present on the Earth's surface and the events' (Tarisayi 2018:186). Another view suggests that GIS is 'a system designed to capture, store, manipulate, analyse, manage and present all types of geographical data' (Peuralahti 2014:8). Johansson (2003:1) holds the view that GIS is 'a tool to collect regional data and produce thematic maps'. Hence, in contemporary literature, there is an apparent consensus among scholars on the fact that GIS is a computer-based tool utilised in processing geographical data. Musa et al. (2013) state:

GIS have been used in a wide variety of fields, including the natural, social, engineering, and particularly the medical sciences because of their ability to incorporate physical, biological, cultural, demographic, or economic information. (p. 112)

Macdevette, Fincham and Forsyth (2005) reveal that GIS is utilised in South Africa by the private sector, local governments, departments, national parastatals and national government. 
Another equally important concept in understanding GIS implementation in geography is the GIScience. GIScience is broader than GIS, which are essentially software tools. According to Goodchild (2006), GIScience is broader than GIS because of its inclusion of spatial analysis, visualisation and the representation of uncertainty. Fleming (2016) suggests that a number of core GIS competencies feed into the geoscience industry.

\section{Geographic Information System implementation in schools}

The GIS implementation in schools has a relatively shorter history as compared to GIS implementation in other sectors of the economy. The GIS implementation in schools has been a topical issue in recent years globally. Countries such as the United States and Finland are among the countries that have adopted GIS into their secondary school geography curriculum (Johansson 2003; Kerski 2003). Goodchild and Kemp (1990) reveal that GIS use in secondary schools began in the early 1990s. However, in South Africa, GIS implementation in schools was introduced as part of the National Curriculum Statement (NCS) in 2006 (Breetzke et al. 2011). However, some South African schools, mainly private schools, had introduced GIS prior to NCS (Innes 2012). Ramsaroop (2018) states that in South Africa GIS is a compulsory component of Geography Curriculum and Assessment Policy Statement (CAPS) in grades 10-12. Grange and Ontong (2018) note that despite challenges such as lack of resources and inadequate teacher training in many schools, the inclusion of GIS in the curriculum in South Africa is a step in the right direction. Geographic Information System is recognised globally as promoting inquiry-based learning environment (Kerski et al. 2013). Geographic Information System facilitates problembased learning (PBL) and inquiry-based learning in the secondary school curriculum (Johansson 2003; Kerski et al. 2013). Because of its facilitation of PBL and inquiry-based learning, GIS essentially supports the constructivist learning approach (Kerski 2008; Kerski et al. 2013). Johansson (2003:2) states that 'problem-based learning (PBL) and inquiry-based learning are instructional methods, which are based on constructivism and are challenging the customary methods used in secondary schools'. In addition, Innes (2012) holds the view that the route to being a GIS professional begins with acquisition of map skills in a geography secondary school classroom. Hence, we argue that GIS in schools provides a foundation for learners to pursue careers in GIS and GIScience professions.

Studies have further acknowledged the pedagogical benefits of GIS implementation in schools. Goodchild and Kemp (1990) state that GIS inspires learners to pursue careers in science and engineering. Equally important is the role of GIS in motivating learners to learn geography (Akinyemi 2015). Geographic Information System is also reportedly vital in the learning of geographical principles (Akinyemi 2015). Hence, we argue that GIS implementation in schools has both classroom benefits (motivating learners to learn geography) and future career benefits (motivating learners to pursue careers in science and engineering). However, it is apparent that schools in South Africa in their endeavour to implement GIS are being curtailed by a number of challenges.

Studies indicate that the majority of schools in South Africa are teaching a basic introduction to GIS and thus the latter is not taught well because learners are not given the opportunity to engage in practical (Ahiaku \& Mncube 2018; Dube 2012; Malatji \& Singh 2018). In addition, Tarisayi (2018) notes that the teaching of GIS in South Africa is hindered by a lack of funding and time constraints (see also Fleming 2016; Nxele 2007; Zuma 2016). Innes (2012:102) argues that despite the promotion of information technology in South African education, 'there is still no national roll-out of resources that makes use of GIS in geography education available to all learners'. The lack of the necessary hardware and software in schools in South African schools affects the implementation of GIS (Carolissen, McPherson \& Kleyn-Magolie 2006; Innes 2012). Hong (2014) and Fleischmann and Van der Westhuizen (2016) state that there is a low adoption of GIS technology in schools because teachers lack knowledge of the practical GIS integration. Studies by Ahiaku and Mcube (2018), Dube (2012), Malatji and Singh (2018), Mzuza and Van Der Westhuizen (2019) and Tarisayi (2018) were all focused on the views of the educators with respect to GIS in schools. Resultantly, Fleming (2016) noted that in 2014 and 2015, respectively, GIS questions in the Matric Geography Paper 2 were often not attempted by the candidates. Mzuza and Van Der Westhuizen (2019) sum the challenges in teaching of GIS in Southern Africa as:

[T] he absence of GIS education in secondary school curricula, the shortage of experienced teachers, the lack of knowledge and technical expertise, the unwillingness of teachers to change their mode of teaching, a shortage of funds and inadequate resources. (p. 1)

Hence, it can be argued that a multiplicity of challenges curtail the teaching of GIS in schools.

\section{Conceptual framework}

In order to reveal learners' understanding of GIS as well as how they link GIS concepts with a real-life situation, we frame this article using a derivative from Robert Chambers' (2012) treatise 'Whose Reality Counts'. As described by Chambers (2012), in the context of development and addressing social issues, there are multiple realities to the poverty phenomena. Chambers (1995) explains that the poor hold realities which are different from those of professionals and development experts. The realities of the professionals are informed by their positionality. Chambers argues that often than not in the arena of poverty alleviation interventions, the realities of professionals are prioritised while neglecting the views of the poor. Therefore, this article stems from our realisation that there are multiple realities regarding GIS implementation in secondary schools in South Africa. However, worrisome is the fact that discourse on GIS implementation has tended to be informed by an educator perspective while oblivious to the 
fact that there are multiple realities. Subsequently, guided by Chambers' argument, we advocate and prioritise the learners' perspective in the implementation of GIS in secondary schools. Furthermore, we argue that the realities of the learners should be valued as compared to those of teachers because these are the ultimate beneficiaries of the GIS implementation. Guided by Chambers' treatise, this study prioritises the learners' realities which are apparently consistent with learner-centred pedagogy. Learner-centred pedagogy advocates that learners should be active participants in their own learning (Weimer 2012). Resultantly, it follows that the views of learners should take precedence in seeking to understand the implementation of GIS in secondary schools in South Africa.

\section{Methodology}

The researchers adopted a qualitative collective case study approach. In order to gain an insight into the learners' perspective on GIS implementation, this study falls in the interpretivist paradigm. Cohen, Manion and Morrison (2018:9) stated that interpretivism entails 'existential understanding and meaning-making'. Qualitative research is naturalist enquiry and it is focused on meaning-making (Neuman 2013) in order to understand people's lived experiences. In this case, learners' understanding of GIS as well as how they link GIS concepts with real-life situations is explored. Creswell and Poth (2018) identified three types of case studies: single instrumental case study, collective case study and intrinsic case study. For this study we adopted a collective case study because in this study we focused on pursuing the learners' perspective of GIS implementation by selecting the case of KwaZulu-Natal province. Data were generated using semi-structured interviews and focus group discussions, allowing us flexibility to probe for clarity (Creswell 2014). There is no consensus on the appropriate sample size in qualitative research. However, Creswell (1998) recommended 5-25 and Morse (1994) suggested at least 6, whereas Crouch and McKenzie (2006) proposed that fewer than 20 participants in a qualitative study aid the researcher to maintain a close relationship with the participants and thus increase the 'open' and 'frank' exchange of information. Thus, a group of 50 learners (10 learners per school) were purposively selected to participate in this study. The learners were selected on the basis that they performed well, obtaining more than $60 \%$ in their geography examinations. Also, these learners had been taught GIS over a 3-year period, starting from grade 10 to grade 12; therefore, they were in a better position to reflect about secondary school GIS implementation that the study aimed at exploring. All the selected learners voluntarily availed themselves for the focus group discussions. The researchers utilised semi-structured interviews to probe themes that emerged from the focus group discussions. Parents gave assent for their children to be interviewed and tape-recorded. Furthermore, the learners also gave consent to be interviewed and tape-recorded. The audiorecorded discussions were transcribed verbatim. Thematic analysis was used to analyse data, whereby we familiarised ourselves with data by identifying recurring themes which helped us to categorise data in order to report findings (Clarke \& Braun 2013). The themes inform the analysis which is presented below. In this article, for ethical reasons, the names of the participants were not used. The researchers used ellipses such as: letter and numbers, such as L1 for learner 1, L2 for learner 2, L8 for learner 8 and L4 for learner 4, to identify interview participants. This study adhered to the research ethics stipulated by the university that granted permission for this study to be conducted.

\section{Findings of this study}

The findings of this study are presented in this section as verbatim narrations. In initial conversations with the learners, questions were posed on their understanding of GIS and the teaching of GIS at the participant school.

\section{Lack of proper understanding of Geographic Information System}

This study established that there was a compelling argument that there was a lack of proper understanding of GIS among the participants. L1 revealed that:

'I had always wondered how GIS worked as in the definition it is said that it is a computerized system that stores data. I had to use my father's laptop to get to it but there was no indication of GIS there and also once I got a chance to use a computer at school which is a rare case, I opened it with the aim of finding GIS but there was also no sign of it. It was then that I realized that a program or software should be installed which took me back and made me understand the components of GIS and software is one of the components of GIS.' (L1, Female, 17 years, Grade 12)

Hence, it can be noted from the above-mentioned verbatim narration that there was a lack of proper appreciation of GIS among the grade 12 learners who participated in this study. There was a tacit admission by the grade 12 learners who participated in the focus group discussions that they did not understand the concept of GIS. Lack of proper understanding of GIS was evident in the initial assumption among the grade 12 learners who participated that every computer has GIS. L1 admitted that he initially checked his father's laptop and computers at his school for GIS in vain.

The lack of proper understanding of GIS by the grade 12 learners was evident by failure to relate Global Positioning System (GPS) to GIS. While it was apparent that all the grade 12 learners who participated in the focus group discussion knew about GPS and its use, there was failure to understand the role of GIS in GPS. In the focus group discussion, the grade 12 learners were asked how drivers navigate and locate place in big cities and they all identified GPS. L10 indicated:

'Drivers in South Africa use GPS on their cell phones or inbuilt GPS in their cars in order to avoid being lost.' (L10, Male, 18 years, Grade 12)

It was obvious from the way the grade 12 learners who participated in this study that GPS used by drivers in South Africa was common, but surprisingly the learners failed to appreciate the connection between GPS and GIS. The failure by the grade 12 learners to link the GIS concepts taught in class with GPS, which they later admitted to be in daily use in 
South Africa, further reinforces our argument that there is lack of proper understanding of GIS among grade 12 learners in KwaZulu-Natal province. Therefore, we argue in this study that grade 12 learners lack fundamental knowledge of GIS. These findings concur with Wilmot and Dube (2013), who found that grade 12 learners in South Africa lack fundamental knowledge of GIS. In addition, these findings buttress Chambers' (2012) treatise that the realities of the intended beneficiaries (in this article learners) are essential when implementing and evaluating an intervention or innovation.

The participants in this study further revealed their lack of proper understanding of GIS when they were asked to identify the real-world uses of GIS. Only two of the participants were able to identify the uses of GIS and their verbatim narrations are captured as follows. L7 stated:

'GIS can be used by the Department of Safety and Security, SAPS when tracking the paths taken by the car hijackers taking cars out of the country.' (L7, Female, 18 years, Grade 12)

Therefore, L7 managed to identify GIS use in story-mapping and trail identification by the police.

\section{L2 indicated:}

'The Department of Health uses the numbers from the clinics to find out about the numbers of people who suffer from TB [tuberculosis] then when they look at the numbers they then see the need to have fixed and permanent clinics.' (L2, Male, 17 years, Grade 12)

L2 identified the role of GIS in disease surveillance as a public health tool. However, it can be noted that both contributions by L7 and L2 seemed to have identified two different uses of GIS, which on closer scrutiny are in actual fact both classified under mapping. In addition, it also emerged from the focus group discussion that the learners were only able to relate GIS to mapping. Different professions utilise GIS to provide visual interpretations of their profession-related data as in the cases of police and health identified by L7 and L2, respectively. Musa et al. (2013) state that because of its ability to incorporate varying information, GIS is utilised in different fields. Contemporary literature enumerates numerous uses of GIS in different fields, but surprisingly the grade 12 learners who participated in this study only managed to highlight GIS use in mapping. Thus, we argue that the failure by the grade 12 learners to identify the multiplicity of GIS uses in all government departments of South Africa as well as private sector aptly buttresses the notion that there is a lack of proper understanding of GIS. Therefore, it can be argued that the learners who participated in this study lacked a proper understanding of GIS.

\section{Geographic Information System was poorly taught}

In addition, this study also established a host of factors that cumulatively are utilised to explain the lack of proper understanding of GIS by grade 12 learners already discussed in the previous section:
'I have no idea at all of what GIS is, in Grade 10 I had to memorize the concepts in order to answer the question or at times not to answer it at all as I could pass Map work without GIS.' (L2, Male, 17 years, Grade 12)

'I memorized the concepts of GIS in Grade 10 but in Grade 11 I came to understand one thing clearly, that of resolution.' (L3, Female, 18 years, Grade 12)

L2 and L3 admitted that because of failure to grasp the concept of GIS, they resorted to memorising the concepts. Learners in the focus group discussion concurred that they learnt GIS through memorising the concepts. Hence, we argue that GIS was being poorly taught at the school that participated in this study resulting in learners resorting to memorising (without conceptual understanding). This finding concurs with conclusions proffered by other scholars (Ahiaku \& Mncube 2018; Dube 2012; Malatji \& Singh 2018) that GIS was not being properly taught in the South African classroom. Geographic Information System concepts that should be taught as practical aspects of geography are thus being taught as through rote learning which leads learners to memorising concepts instead of properly grasping the concepts.

In addition, it was evident that the grade 12 learners who participated in this study only managed to identify GIS use in mapping when asked to identify GIS use by government departments and the private sector in South Africa. It also emerged from the focus group discussions that GIS was not taught properly in schools that participated in this study. The failure by the learners who participated in this study to identify GIS uses suggests further that GIS was not being properly taught. Felix (2013) prescribes that in the teaching of geography the educator should strive to provide examples in the learner's known environment moving outward to the unknown. However, that was not the apparent situation as revealed by the views of the learners in the focus group discussions. Therefore, we argue that grade 12 learners should have been able to identify GIS uses by the local municipality of EThekwini if GIS was being properly taught in schools in KwaZulu-Natal. Resultantly, we reason that failure to identify uses of GIS in the real world by the grade 12 learners feeds into the growing discourse which argues that GIS is not being properly taught in South African schools (Ahiaku \& Mncube 2018; Dube 2012; Malatji \& Singh 2018).

In addition, it was noted from this study that GIS was not being allocated adequate time on the timetable:

'The teacher only teaches us for a few times in a year so I cannot get it clearly how all these concepts are associated with GIS.' (L2, Male, 17 years, Grade 12)

L2 revealed that GIS was rarely taught throughout the year. The inadequacy of the time allocated to teaching GIS was compounded by rare opportunity accorded learners to use computers as revealed by L1, who stated:

'... [A]lso once I got a chance to use a computer at school which is a rare case.' (L1, Female, 17 years, Grade 12) 
It was noted from participant (L1) that there was limited use of computers at their school. This was contrary to the fact that GIS requires a hands-on approach entailing taking practical lessons. In addition, the Department of Basic Education (2011:7) advocates in the CAPS for 'promoting the use of new technologies, such as Information Communication Technology (ICT) and Geographical Information Systems (GIS)' among grades 10, 11 and 12 learners. Thus, the way GIS was being taught in schools was contrary to the CAPS promotion because teachers were teaching GIS a few times. We further argue that there is evidently a gap between the CAPS prescriptions and the situation in the geography classroom in KwaZulu-Natal province as far as the teaching of GIS is concerned. We argue that the lack of proper understanding of the concept of GIS established in this study can be attributed to time constraints in the teaching of GIS.

\section{Additional observations}

This study further established that there were challenges in the assessment of GIS in the geography grade 12 curriculum. The learners who participated in the focus group discussions revealed that despite their poor understanding of GIS, they still passed the examinations. L6 indicated:

'I am still in the dark but I pass GIS, only God knows how.' (L6, Female, 17 years, Grade 12)

L6 admitted that she had a vague understanding of GIS, but somehow surprisingly she passed the GIS questions in the examinations. Therefore, there was an admission by the participants that they were not well versed with GIS, but passed geography examinations all the same which included questions on GIS. Consequently, we noted that it was evidently possible to pass the geography examination without a good grasp of GIS. In addition, the fact that learners managed to pass the geography examination which includes a section on GIS brings to the fore questions on the validity of the geography examination as a vehicle for assessing the teaching of GIS to a certain extent. Hence, we noted that despite the grade 12 learners' lack of fundamental knowledge of GIS, they somehow passed examinations.

In addition, questions on the validity of geography examinations in relation to GIS are strengthened by grade 12 learners' choice of GIS they preferred. L5 revealed:

'I like the questions on the uses of GIS in a farming area because this question is similar to the questions that are asked in map interpretation in map work.' (L5, Male, 18 years, Grade 12)

A closer scrutiny of the preferred type of GIS question revealed that grade 12 learners were being asked data recall questions. This aptly reveals that grade 12 learners were being asked data recall questions which can be used to explain why learners were passing geography examinations without a proper understanding of GIS. Data recall questions mostly require learners to remember information without necessarily putting it into use. Hence, we reasoned that grade 12 learners passed their geography examinations despite

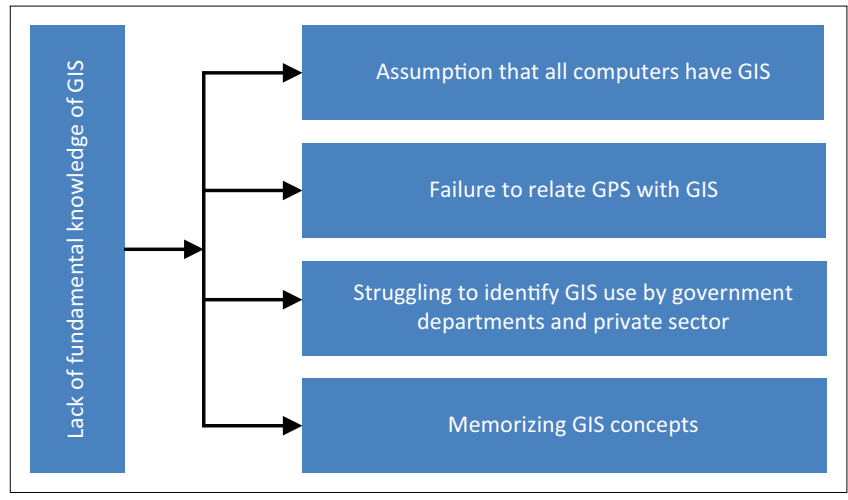

GIS, Geographic Information System.

FIGURE 1: Themes on lack of fundamental knowledge of Geographic Information System.

an apparent lack of fundamental GIS knowledge because of the posing of data recall questions which call for the memorising of concepts. In addition, data recall questions, which were preferred by the participants in this study, can be classified as knowledge questions according to Bloom's taxonomy of thinking (Adams 2015). Knowledge questions seek to assess the learner's ability to remember information previously learned material.

\section{Conclusion}

This study concludes that there was a lack of fundamental knowledge of GIS amongst the grade 12 learners who participated in this study. The themes that emerged to support the view that grade 12 learners lacked fundamental knowledge of GIS are shown in Figure 1. Among the themes identified are the assumptions that all computers have GIS, failure to relate GPS with GIS, struggling to identify GIS use by government departments and private sector and memorising GIS concepts.

Furthermore, the learners' perspective on GIS implementation established in this study converged with the educators' perspectives submitted by Malatji and Singh (2018), Ahiaku and Mncube (2018) and Dube (2012). This study was in agreement with contemporary research on GIS implementation in South Africa that grade 12 learners lacked fundamental knowledge of GIS. This study established that GIS was not being properly taught at the schools which participated in this study. It was also evident that grade 12 learners were mainly asked data recall questions in the examination of GIS. Consequently, there was a convergence of views between the educators' and learners' perspectives on GIS implementation in Kwazulu-Natal province.

\section{Acknowledgements Competing interests}

The authors have declared that no competing interests exist.

\section{Authors' contributions}

All authors contributed equally to this work. 


\section{Ethical consideration}

Ethical clearance to conduct the study was obtained from the University of Kwazulu-Natal (Reference number: HSS1519/018D).

\section{Funding information}

This research received no specific grant from any funding agency in the public, commercial or not-for-profit sectors.

\section{Data availability statement}

Data sharing is not applicable to this article as no new data were created or analysed in this study.

\section{Disclaimer}

The views and opinions expressed in this article are those of the authors and do not necessarily reflect the official policy or position of any affiliated agency of the authors.

\section{References}

Adams, N.E., 2015, 'Bloom's taxonomy of cognitive learning objectives', Journal of Medical Library Association 103(3), 152-153, https://doi.org/10.3163/1536 5050.103.3.010

Ahiaku, P.K.A. \& Mncube, D.W., 2018, 'Geography educators' perceptions of learner performance in grade 12 Geography in public schools', Alternation Special Edition $21,68-90$.

Akinyemi, F.O., 2015, 'An assessment of GIS use for teaching in Rwandan secondary schools' The Geography Teacher 12(1), 27-40. https://doi.org/10.1080/1933834 1.2014.975144
schools', The Geg

Breetzke, G.D., Eksteen, S. \& Pretorius, E., 2011, 'Paper-based GIS: A practical answer to the implementation of GIS education into resource-poor schools in South Africa', Journal of Geography 110(4), 1-10.

Carolissen, M., McPherson, E. \& Kleyn-Magolie, B., 2006, 'Perceptions and challenges facing educators with the introduction of GIS into the school curriculum: Western Cape, South Africa', Paper presented at the International Geographical Union Commission on Geographical Education Symposium, IGU CGE and Royal Geographical Society of Queensland, Brisbane, July 29-31, 2006.

Chambers, R., 1995, 'Poverty and livelihoods: Whose reality counts?', Environment and Urbanization 7 (1), 173-204. https://doi.org/10.1177/095624789500700106

Chambers, R., 2012, 'Poverty and livelihoods: Whose reality counts?', in R. Jolly (ed.), Milestones and turning points in Development thinking, pp. 101-117, Palgrave Macmillan, London.

Clarke, V. \& Braun, V., 2013, 'Teaching thematic analysis: Overcoming challenges and developing strategies for effective learning', The psychologist 26(2), 120-123.

Cohen, L., Manion, L. \& Morrison, K., 2018, Research methods in education, Routledge, London.

Creswell, J.W., 1998, Qualitative inquiry and research design: Choosing among five traditions, Sage, Thousand Oaks, CA.

Creswell, J.W., 2014, Research design: Qualitative, quantitative, and mixed methods approaches, Sage, London.

Creswell, J.W. \& Poth, C.N., 2018, Qualitative inquiry and research design: Choosing among five approaches, Sage, Thousand Oaks, CA.

Crouch, M. \& McKenzie, H., 2006, 'The logic of small samples in interview-based qualitative research', Social Science Information 45(4), 483-499. https://doi.org/ 10.1177/0539018406069584

Department of Basic Education, 2011, Curriculum and assessment policy statement: Grades 10-12, Government Printing, Cape Town.

Dube, J., 2012, A case for improving teaching and learning in South African higher education, Council on Higher Education, Pretoria.

Felix, D.B., 2013, 'Effects of inductive thinking model of teaching on the development of competencies in the learning of geography among secondary students in Seychelles', Master's thesis, University of Mysore.
Fleischmann, E.M. \& Van der Westhuizen, C.P., 2016, 'A GIS integrational framework for poorly resourced schools', Journal of Geography Education for Southern Africa 1(2), 25-33.

Fleming, B., 2016, 'GIS interventions at secondary level education in South Africa-some recent successes and shortfalls', Journal of Geography Education for Southern Africa 1(2), 9-24.

Goodchild, M.F., 2006, 'GIScience ten years after ground truth', Transactions in GIS 10(5), 687-692. https://doi.org/10.1111/j.1467-9671.2006.01022.x

Goodchild, M.F. \& Kemp K.K. (eds.), 1990, National Centre Geographic Information and Analysis (NCGIA) core curriculum in GIS, National Centre for Geographic Information and Analysis, Santa Barbara, CA.

Grange, L. \& Ontong, K., 2018, 'Towards an integrated school Geography curriculum: The role of place-based education', Alternation Special Edition 21(2018), 12-36. https://doi.org/10.29086/2519-5476/2018/sp21a2

Hong, J.E., 2014, 'Promoting teacher adoption of GIS using teacher-centered and teacher-friendly design', Journal of Geography 113(4), 139-150. https://doi.org/ 10.1080/00221341.2013.872171

Innes, L.M., 2012, 'South African School Geography: Underpinning the foundation of geospatial competence', South African Journal of Geomatics 1(1), 92-108.

Johansson, T., 2003, 'GIS in teacher education-facilitating GIS applications in Secondary School Geography', in ScanGIS, 285-293.

Kerski, J.J., 2003, 'The implementation and effectiveness of Geographic Information Systems technology and methods in secondary education', Journal of Geography 102(4), 128-137. https://doi.org/10.1080/00221340308978534

Kerski, J.J., 2008, 'The role of GIS in Digital Earth education', International Journal of Digital Earth, 1:4, 326-346. https://doi.org/10.1080/17538940802420879

Kerski, J.J., Demirci, A. \& Milson, A.J., 2013, 'The global landscape of GIS in secondary education', Journal of Geography 112(6), 232-247. https://doi.org/10.1080/0022 1341.2013.801506

Macdevette, D.R., Fincham, R.J. \& Forsyth, G.G., 2005, 'The rebuilding of a country: The role of GIS in South Africa', in P.A. Longley, M.F. Goodchild, D.J. Maguire \& D.W. Rhind (eds.), Geographical information systems, pp. 913-924, Wiley, New York.

Malatji, K.S. \& Singh, R.J., 2018, 'Implications of the articulation gap between Geography learners in secondary schools and university', Alternation Specia Edition 21(2018), 91-108. https://doi.org/10.29086/2519-5476/2018/sp21a5

Morse, J.M., 1994, 'Designing funded qualitative research', in N.K. Denizin \& Y.S. Lincoln (eds.), Handbook of qualitative research, pp. 220-235, Sage, Thousand Oaks, CA.

Musa, G.J., Chiang, P., Sylk, T., Bavley, T., Keating, W., Lakew, B. et al., 2013, 'Use of GIS mapping as a public health tool-from cholera to cancer', Health Services Insights 6, 111-116. https://doi.org/10.4137/HSI.S10471

Mzuza, M.K. \& Van Der Westhuizen, C.P., 2019, 'Review on the state of GIS application in secondary schools in the southern African region', South African Geographical Journal 101(2), 175-191. https://doi.org/10.1080/03736245.2019.1579110

Neuman, W.L., 2011, Basics of social research: Qualitative and quantitative approaches, Pearson Education Limited, London.

Nxele, A., 2007, 'The impact of the transition from Grade 7-9 to FET (Grade 10-12) on the teaching and learning of Geography in Eastern Cape Schools', Paper presented at the Society of South African Geographers, Nelson Mandela Metropolitan University, Port Elizabeth, July 8-11, 2007.

Ozgen, N., 2009, 'The functionality of a Geography Information System (GIS) technology in Geography teaching: Application of a sample lesson', Educational Sciences, Theory and Practice 9(4), 1879-1894.

Palladino, S., 1994, 'A role for Geographic Information Systems in the secondary schools: An assessment of the current status and future possibilities. Perspectives and resources for GIScience education', viewed 31 January 2019, from http://escholarship.org/uc/item/6p93g6wd.

Peuralahti, J., 2014, 'Geographic Information System - A case study for developers', Master thesis, Department of Geography, Helsinki Metropolitan University of Applied Sciences.

Ramsaroop, S., 2018, "Bringing map learning to "life" by using the environment as a learning resource', Alternation Special Edition 21(2018), 109-130. https://doi.org/ 10.29086/2519-5476/2018/sp21a6

Tarisayi, K.S., 2018, 'Lessons for GIS implementation in Zimbabwe', Alternation Special Edition 21(2018), 185-202. https://doi.org/10.29086/2519-5476/2018/sp21a9

Weimer, M., 2012, 'Five characteristics of learner-centred teaching. Effective teaching strategies', viewed 31 January 2019, from www.facultyfocus.com/articles/ effective-teaching-strategies/five-characteristics-of-Ireaner-centred-teaching/.

Wilmot, D. \& Dube, C., 2015, 'School Geography in South Africa after two decades of democracy: Teachers' experiences of curriculum change', Geography 100(2), 94-101.

Wilson, J.P. \& Fotheringham, A.S. (eds.), 2007, The handbook of geographic information science, Blackwell Publishing, Malden, MA.

Zuma, S., 2016, 'Teachers' reflections of teaching Geographical Information System (GIS) at Grade 11 within CAPS in a township school in the uMhlathuze Circuit', Master's thesis, Department of Geography Education, University of KwaZuluNatal, Durban. 